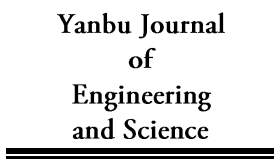

ISSN: $1658-5321$
Vol. 14, June 2017 (1438H)

www.yjes.org.sa

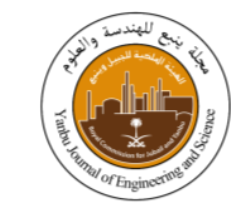

\title{
TECHNO-ECONOMIC FEASIBILITY OF A HYBRID SOLAR PV AND WIND POWER SYSTEM FOR YANBU, SAUDI ARABIA
}

\author{
Hazim Moria', Md. Abdullah Hil Baky², Md. Mustafizur Rahman², A.K.M. Sadrul Islam² \\ ${ }^{1}$ Department of Mechanical Engineering Technology, Yanbu Industrial College, Yanbu Al-Sinaiyah 41912, Kingdom of Saudi Arabia \\ ${ }^{2}$ Mechanical \& Chemical Eng. Department, Islamic University of Technology, Board Bazar, Gazipur 1704, Bangladesh \\ E-mail:moriah@rcyci.edu.sa
}

\begin{abstract}
Energy from renewable sources is being increasingly exploited for meeting the power demands and reducing the harmful impact of burning the fossil fuels on the environment. Solar photovoltaic and wind turbine are being incorporated with the conventional diesel generator to reduce the fuel consumption. Saudi Arabia, being a country with high intensity of solar radiation, has good potential of using solar PV system. In this study, a solar wind hybrid system is modeled using HOMER to find an optimum system to meet the load requirement of a community at Yanbu city. The primary load of the community of 500 people is $556 \mathrm{kWh} /$ day with $68 \mathrm{~kW}$ peak. The analysis showed that $200 \mathrm{~kW}$ PV system is the most economically feasible to meet the proposed demand and the minimum cost of energy for this system is $0.617 \$ / \mathrm{kWh}$. Sensitivity analysis was carried out by varying average wind speed and solar radiation and is presented in this study.
\end{abstract}

Keywords: Yanbu, Saudi Arabia, hybrid, PV, wind, techno-economic analysis.

\section{INTRODUCTION}

The share of fossil fuel in the primary energy consumption in recent times is almost $86 \%$ and is further increasing gradually with the industrialization $[1,2]$. This high usage of fossil fuel results in increased amount of greenhouse gas emissions. Around 34.7 billion tons of $\mathrm{CO}_{2}$ has been emitted in 2014 and is expected to increase by $85 \%$ within 2030 [3-5]. Incorporating renewable energy means reducing the consumption of conventional fuels hence reducing greenhouse gas emissions. Transportation and power sectors are the major consumers of fossil fuels. Transportation sector mainly utilizes the petroleum products while coal and natural gas are used for electricity generation. There are still around two billion people around the world in different countries who are living in areas where the extension of grid electricity is not possible or is not cost efficient because of the dispersed nature of that area [6]. Diesel generator is the only option of power generation in such areas but it is expensive. Continuous supply of diesel to these remote and disperse areas is risky. Moreover, about 1.2 billion people worldwide are deprived of electricity [7]. However, to reduce the greenhouse gas emissions and to ensure power supply, 
renewable energy source with or without diesel generators is a viable option. This combination of different renewable energy and diesel generator with or without battery backup is known as a hybrid energy system and is being practiced for the last couple of years and is environmentally benign [8]. This will reduce the fuel transport, storage and consumption resulting in a lower risk of fuel spills and increased engine life. Various combinations such as wind-PV diesel, winddiesel, PV-diesel, wind-PV etc. are being used for electricity production. Hybrid power systems are more reliable and cost efficient compared to stand alone PV, wind, or diesel power systems. PV wind system alone cannot supply power on a 24 hour basis due to unavailability of solar energy or wind continuously [9]. Again, standalone diesel system is expensive and maintenance cost is high [10]. Therefore, diesel, PV, and wind energy systems can be used as complimentary to each other. To ensure regular power supply and minimize the fluctuation; battery storage is also incorporated into the hybrid power systems $[11,12]$. In order to reduce the greenhouse emission by $100 \%$, the techno-economic analysis of a hybrid system without diesel engine system is also analyzed. Several authors [13-20] have analyzed the technoeconomic aspects of different hybrid power systems of different sizes and wind load energy. Rahman et al evaluated the effect of diesel generator of the hybrid energy system on the cost of energy [7]. In that study, they have developed seven scenarios and six of them were based on different renewable energy penetrations such as $100 \%, 80 \%$, $65 \%, 50 \%, 35 \%$ and $21 \%$ and the last one was only diesel and battery system. The systems were set to meet the load requirement of $4.4 \mathrm{MW} /$ day with a peak load of $772 \mathrm{~kW}$. The study resulted in cost of energy of $\$ 1.48 / \mathrm{kWh}, \quad \$ 0.62 / \mathrm{kWh}$, $\$ 0.54 / \mathrm{kWh}, \quad \$ 0.42 / \mathrm{kWh}, \quad \$ 0.39 / \mathrm{kWh}$, $\$ 0.37 / \mathrm{kWh}$ and $\$ 0.36 / \mathrm{kWh}$ for $100 \%, 80 \%$, 65\%, 50\%, 35\%, 21\% renewable energy and battery diesel generator system respectively. According to a study carried out by Kusakana et al, the cost of energy for a hybrid PV and wind system and PV, wind, and diesel only systems were $\$ 0.372 / \mathrm{kWh}$, $\$ 0.393 / \mathrm{kWh}, \$ 0.53 / \mathrm{kWh}$ and $\$ 1.34 / \mathrm{kWh}$ respectively [21]. Shaahid and El-Amin performed a techno-economic analysis of a PV-diesel battery hybrid energy system designed for electrification of Kahfa, Saudi Arabia [6]. The cost of generating energy from the hybrid system was found to be $\$ 0.17 / \mathrm{kWh}$ with $27 \% \mathrm{PV}$ penetration. Also, Nandi and Ghosh studied the PV windbattery hybrid system for Chittagong, Bangladesh [22]. For $4.36 \mathrm{kWh} / \mathrm{m}^{2} /$ day of solar radiation and $3-5 \mathrm{~m} / \mathrm{s}$ of wind speed the cost of generating energy was found to be $\$ 0.47 / \mathrm{kWh}$ with $53 \%$ wind energy penetration for $10 \%$ annual capacity shortage. This paper aims at analyzing the solar and wind data of Yanbu city and study the feasibility of a solar wind battery hybrid energy system to supply electricity to a community of 500 inhabitants in Yanbu.

\section{EXPERIMENTAL}

\subsection{Renewable ENergy AND Hybrid System SETUP}

Hybrid power system allows the different combination of PV, wind, battery and diesel engines. This benefit in establishing a system according at any sites the available energy resources, cost and load demands. The hybrid renewable energy system considered in this study is a combination of wind, PV, battery and an inverter and it is designed to meet the load requirement of the community under investigation. 
The schematic diagram of the hybrid system used here is presented in Figure 1. The output from the Renewable Energy System (RES) being insufficient to meet the load requirement, the battery will discharge to meet the demand. On the other hand, if the RES produces more than the required demand, the excess energy will be stored in the battery. In the case when the battery is full and output from RES is more than the required load demand, the energy will be dumped. The hybrid power optimization tool HOMER (Hybrid Optimization Model for Electric Renewable) has been used in this study to simulate the best size of the hybrid system. In addition, to meet the certain demand of the city based upon the minimum net present cost.

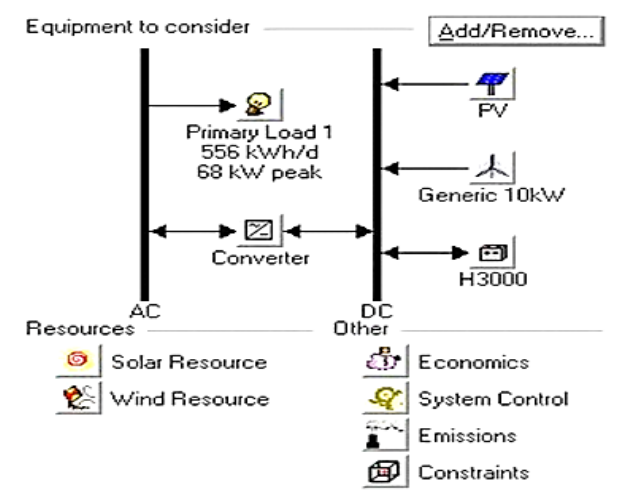

Fig.1. Schematic diagram of the hybrid renewable energy system

\subsection{SiMULATION TOOLS}

HOMER is a computer model developed by National Renewable Energy Laboratory (NREL) to design standalone renewable energy power systems [23]. Both off grid and grid connected power systems can be designed by this sophisticated computer model for different applications. Based upon the inputs, given as technology options, components costs, and resource availability, the software simulates different system configurations, components combinations and generates the result of feasible configurations based on Net Present Cost (NPC). NPC is the representation of the life cycle cost of a system which takes into consideration all costs occurring within the project lifetime such as initial cost, replacement cost, operation and maintenance cost etc. and all of these are assumed to be increasing at the same rate over the years based on an annual real interest rate. The software also takes in to consideration the salvage value of all the components at the end of the lifetime. In order to analyse the effect of different factors on the cost effectiveness of different system configuration, this tool allows sensitivity analysis. The software simulates each system configuration over the range of the sensitivity variables which allows seeing the effect of changes of sensitivity variables on the simulation results.

\subsection{SITE SELECTION AND RESOURCE ASSESSMENT}

\subsubsection{SITE SELECTION}

The site considered in this study is a community of Yanbu, a port city in the $\mathrm{Al}$ Madinah state of KSA. It is approximately $330 \mathrm{~km}$ northwest of Jeddah. Its geographical coordinates are $24^{\circ} 05^{\prime} \mathrm{N} 38^{\circ} 00^{\prime} \mathrm{E}$. Being Yanbu a port city, it has good wind energy potential as well. The average temperature varies from $27.7^{\circ} \mathrm{C}$ in the month of January to $40.4^{\circ} \mathrm{C}$ in the month of August.

\subsubsection{LOAD DEMAND}

The energy consumption of the community under consideration is $556 \mathrm{kWh} /$ day with a peak load of $67.9 \mathrm{~kW}$. The maximum value of load is assumed to be recorded as $42 \mathrm{~kW}$ in the summer months (April to September) between 14:00 and 15:00 hours. This high load is mainly due to high energy 
consumption by air conditioning, fan and refrigeration units.

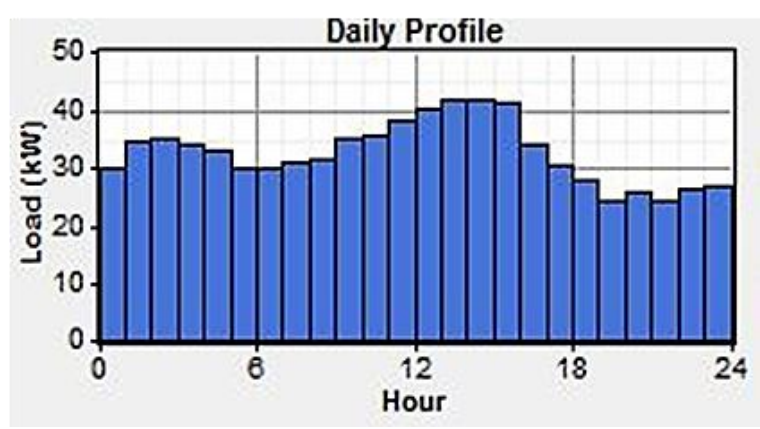

Fig.2. (a) Typical summer day load demand for the community.

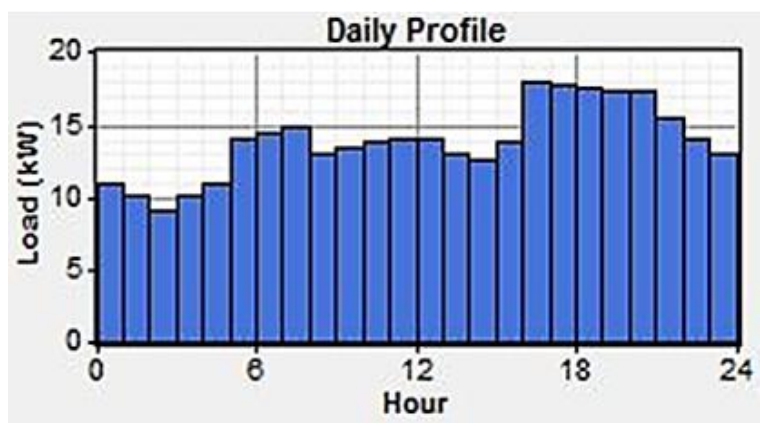

Fig. 2. (b) Typical winter day load demand for the community.

The minimum load of $9 \mathrm{~kW}$ is observed at 03:00 hours in winter months (October to March). The annual load factor is 0.341 . The houses in the community are close to each other and hence distribution cost is neglected. The load demand for the typical summer and winter season are presented in Figure 2 .

\section{RESULTS AND DISCUSSION}

\subsection{RENEWABLE ENERGY RESOURCES}

\subsubsection{SOLAR RADIATION}

HOMER can synthesize hourly solar radiation data for the whole year for any location using Graham algorithm, latitude, and monthly average values. The data generated in this way will not perfectly replicate the characteristics of solar radiation data of the area [24]. In this study, the solar insolation data were taken from the NASA surface meteorology and solar energy database.
Yearly average solar insolation for Yanbu city is $5.95 \mathrm{kWh} / \mathrm{m}^{2} /$ day. The average clearness index is 0.65 . Figure 3 illustrates the monthly solar radiation and clearness index at Yanbu. During the summer months, solar radiation is higher compared to other months and hence higher energy yield is expected.

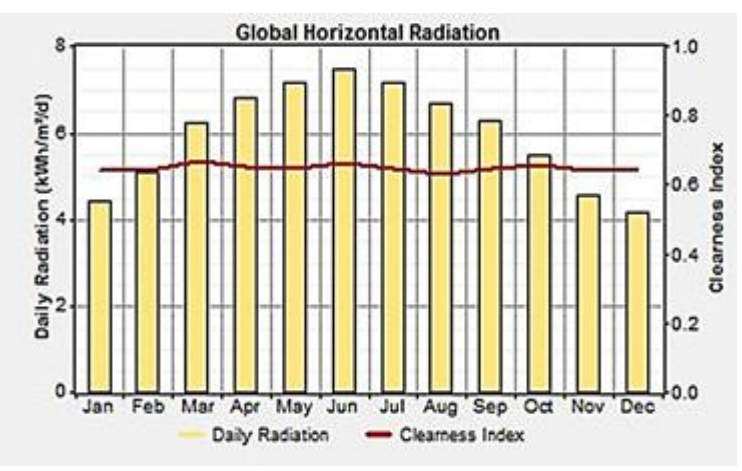

Fig. 3. Monthly solar radiation and clearness index at Yanbu

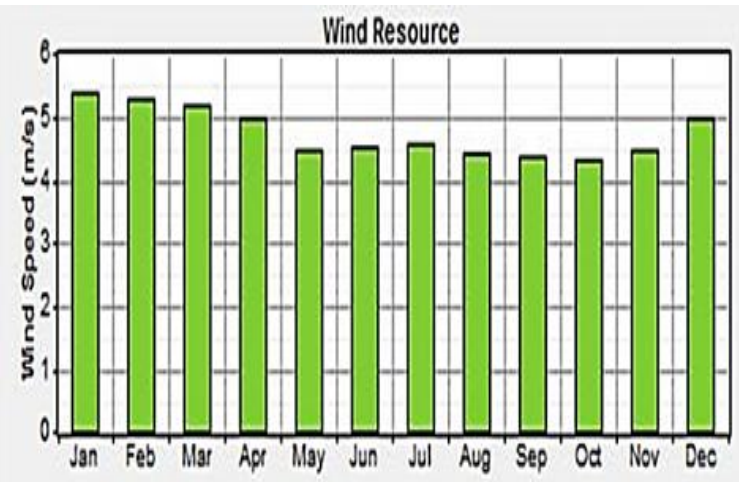

Fig. 4. Monthly average wind speeds variation during year at Yanbu

The wind speed data were also taken from the NASA surface meteorology and solar energy database. These data were taken at a height $50 \mathrm{~m}$ above the surface of the earth. The annual average and monthly peak wind speed are 4.74 and $5.4 \mathrm{~m} / \mathrm{s}$ respectively. Wind speed is higher in the months of December to April compared to other months as shown in Fig. 4. However, in this study wind speeds are varied from 4.5 to 7.5 $\mathrm{m} / \mathrm{s}$ for sensitivity analysis. The parameters such as Weibull distribution factor, autocorrelation factor, diurnal pattern 
strength and the hours of peak wind speed were found to be $2,0.85,0.25$ and 15 hours respectively.

\subsection{HOMER SOFTWARE INPUT DATA}

\subsubsection{HYBRID SYSTEM COMPONENTS AND COST}

The hybrid system considered in this study consists of a PV array, wind turbine, battery and a converter for conversion of DC to AC. The details of these components are provided in the Tables $1,2,3$ and 4 respectively from [25-27]. For PV modules and wind turbines the replacement cost is assumed to be zero because the PV module and wind turbine lifetime are assumed to be 20 years which is same as the system lifetime. The slope of the PV module is taken as $24.2^{\circ}$ and is allowed to vary from $5^{\circ}$ to $40^{\circ}$ for sensitivity analysis. For the wind energy a 'Generic 10 kW' wind turbine and 'Hoppecke $244 \mathrm{OPzS} 3000$ ' batteries are used. Generic $10 \mathrm{~kW}$ wind turbine power curve is shown in Figure 5.

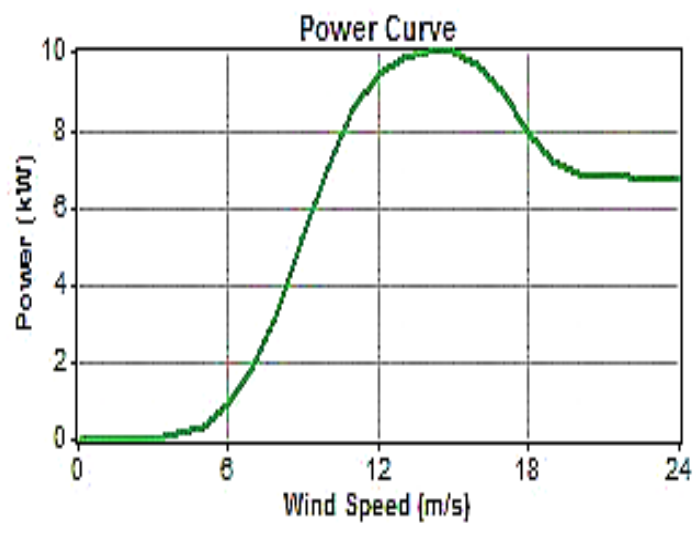

Fig. 5. Generic $10 \mathrm{~kW}$ wind turbine power curve
TABLE 1: TECHNICAL PARAMETERS AND COST ASSUMPTIONS OF PV ARRAY

\begin{tabular}{|c|c|c|}
\hline Parameter & Unit & Value \\
\hline Capital Cost & $\$ / \mathrm{kW}$ & 4000 \\
\hline Replacement Cost & $\$ / \mathrm{kW}$ & 0 \\
\hline $\begin{array}{c}\text { Operation and } \\
\text { Maintenance Cost } \\
(\mathrm{O} \& \mathrm{M})\end{array}$ & $\$ / \mathrm{kW} /$ year & 50 \\
\hline Lifetime & Years & 20 \\
\hline Derating Factor & Percent & 80 \\
\hline Tracking System & Yes/No & No \\
\hline
\end{tabular}

TABLE 2: TECHNICAL PARAMETERS AND COST ASSUMPTIONS OF WIND TURBINE

\begin{tabular}{|c|c|c|}
\hline Parameter & Unit & Value \\
\hline Capital cost & $\$ / \mathrm{kW}$ & 4500 \\
\hline Replacement Cost & $\$ / \mathrm{kW}$ & 0 \\
\hline $\begin{array}{c}\text { Operation and } \\
\text { Maintenance Cost } \\
\text { (O \& M) }\end{array}$ & $\$ / \mathrm{kW} /$ year & 900 \\
\hline Rated Power & $\mathrm{kW}$ & 10 \\
\hline Lifetime & Years & 20 \\
\hline
\end{tabular}

TABLE 3: TECHNICAL PARAMETERS AND COST ASSUMPTIONS OF BATTERY

\begin{tabular}{|c|c|c|}
\hline Parameter & Unit & Value \\
\hline Capital cost & $\$ /$ battery & 1100 \\
\hline Replacement Cost & $\$ /$ battery & 1000 \\
\hline $\begin{array}{c}\text { Operation and Maintenance } \\
\text { Cost (O \& M) }\end{array}$ & $\begin{array}{c}\text { \$battery/ } \\
\text { year }\end{array}$ & 12 \\
\hline Nominal Voltage & Volt & 2 \\
\hline Nominal Capacity & Ah(kWh) & $3000(6)$ \\
\hline Maximum Charge Current & A & 610 \\
\hline Minimum State of Charge & Percent & 30 \\
\hline Round Trip Efficiency & Percent & 86 \\
\hline Number of batteries per & Nos & 10 \\
\hline Minimum battery life & Years & 5 \\
\hline
\end{tabular}


TABLE 4: TECHNICAL PARAMETERS AND COST ASSUMPTIONS OF CONVERTER

\begin{tabular}{|c|c|c|}
\hline Parameter & Unit & Value \\
\hline Capital cost & $\$ / \mathrm{kW}$ & 900 \\
\hline Replacement Cost & $\$ / \mathrm{kW}$ & 900 \\
\hline $\begin{array}{c}\text { Operation and } \\
\text { Maintenance Cost } \\
(\text { O \& M) }\end{array}$ & $\$ / \mathrm{kW} /$ year & 0 \\
\hline Lifetime & Years & 15 \\
\hline Efficiency & Percent & 90 \\
\hline Rectifier Capacity & Percent & 100 \\
\hline Rectifier Efficiency & Percent & 85 \\
\hline
\end{tabular}

\subsubsection{CONTROL PARAMETER AND CONSTRAINTS}

When calculating the present value of the components the software assumes that all prices increase at the same rate over the lifetime known as real interest rate rather than the nominal interest rate. This study considers real interest rate of $6 \%$ and the project lifetime as 20 years. The system control parameters are summarized in Table 5.

TABLE 5: CONSTRAINTS USED IN HOMER

\begin{tabular}{|c|c|}
\hline Parameter & $\begin{array}{c}\text { Value } \\
\text { (\%) }\end{array}$ \\
\hline $\begin{array}{c}\text { Maximum annual capacity } \\
\text { shortage }\end{array}$ & 0 \\
\hline Percent of annual peak load & 0 \\
\hline Percent of hourly load & 10 \\
\hline Percent of hourly solar output & 10 \\
\hline Percent of hourly wind output & 10 \\
\hline Penetration & 100 \\
\hline
\end{tabular}

\section{RESULTS AND DISCUSSION}

Several component configurations were simulated for finding the best renewable energy configuration. Search space showed the different sizing options of the different component for making a simulation as shown in Table 6. Sensitivity inputs of wind speed and slope of PV array are not shown in the search space. A total number of 4,139,520 alternatives consisting of 9,240 systems with 448 sensitivities were formed and consumed around 12 hours and 9 minutes computation time. The optimal system for the original case of $4.74 \mathrm{~m} / \mathrm{s}$ wind speed and $24^{\circ} \mathrm{PV}$ array slope doesn't contain any wind turbine as shown in Figure 6. This is because of the poor wind energy resource compared to high solar energy potential. The effect of higher wind speed than the average, that has been used in the base case, is shown later in the sensitivity analysis.

TABLE 6: SEARCH SPACE OPTIMIZATION

\begin{tabular}{|c|c|c|c|}
\hline $\begin{array}{c}\text { PV Array } \\
(\mathbf{k W})\end{array}$ & $\begin{array}{c}\text { Generic 10, } \\
\text { Quantity }\end{array}$ & $\begin{array}{c}\text { H300, } \\
\text { Strings }\end{array}$ & $\begin{array}{c}\text { Converter } \\
(\mathbf{k W})\end{array}$ \\
\hline 0 & 0 & 0 & 10 \\
\hline 10 & 1 & 10 & 20 \\
\hline 20 & 2 & 14 & 30 \\
\hline 30 & 3 & 18 & 40 \\
\hline 40 & 4 & 20 & 50 \\
\hline- & - & - & - \\
\hline- & - & - & - \\
\hline 290 & 9 & 37 & 90 \\
\hline 300 & 10 & 40 & 100 \\
\hline
\end{tabular}

The optimal solution obtained here consists of a $200 \mathrm{~kW}$ PV, 350 batteries, and $80 \mathrm{~kW}$ converters. Hence, $100 \%$ of the energy demand is met by solar energy. Energy contribution of PV array is shown in Table 7 and the monthly average electricity production from PV is illustrated in Figure 7. 


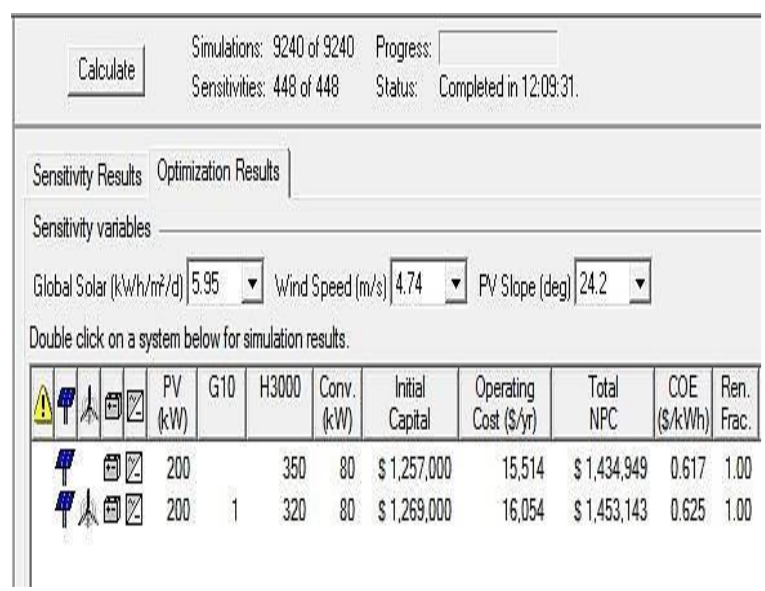

Fig. 6. Optimized result from HOMER

TABLE 7: SEARCH SPACE OPTIMIZATION

\begin{tabular}{|c|c|}
\hline Item Description & PV \\
\hline Rated Capacity, $\mathrm{kW}$ & 200 \\
\hline Capacity Factor, \% & 21.4 \\
\hline Mean output power, $\mathrm{kW}$ & 42.8 \\
\hline $\begin{array}{c}\text { Annual energy output, } \\
\mathrm{kWh} / \text { year }\end{array}$ & 375,139 \\
\hline $\begin{array}{c}\text { Annual hour of operation, } \\
\text { hours }\end{array}$ & 4401 \\
\hline Penetration, \% & 100 \\
\hline
\end{tabular}

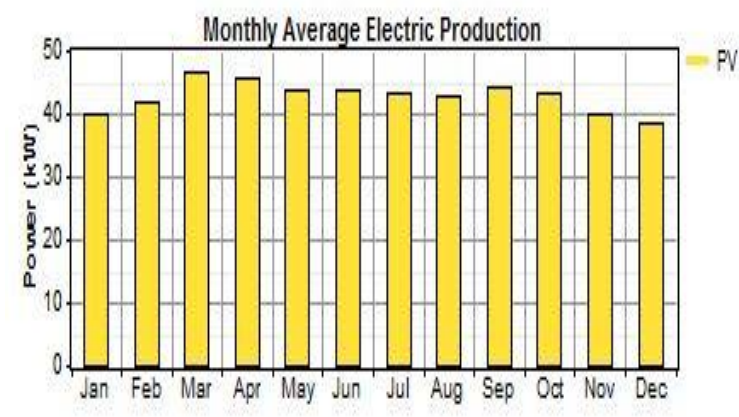

Fig.7. Monthly average electric power production

\subsection{ECONOMIC ANALYSIS}

The total cost of different component of the hybrid system is shown in Figure 8 and NPC of different component are shown in Figure 9. It is clear that most of the NPC is due to PV and the converter contributes the minimum NPC. Total NPC of the system is found to be $\$ 1,434,950$. Leveled cost of energy is estimated to be $0.617 \$ / \mathrm{kWh}$. The capital cost of the proposed system is
$\$ 1,257,000$. The replacement cost, Operation and Maintenance Cost (O \& M) and salvage value are found to be $\$ 30,043$, $\$ 162,043$ and $\$-14,967$ respectively. The replacement cost is small since the PV lifetime is the same as the system lifetime. The corresponding annualized value of the capital, replacement, $\mathrm{O} \& \mathrm{M}$ costs and salvage values are $\$ 109,591, \$ 2,619$, $\$ 14,200$ and $\$-1,305$ respectively. Since no diesel generator has been used all fuel costs are zero.

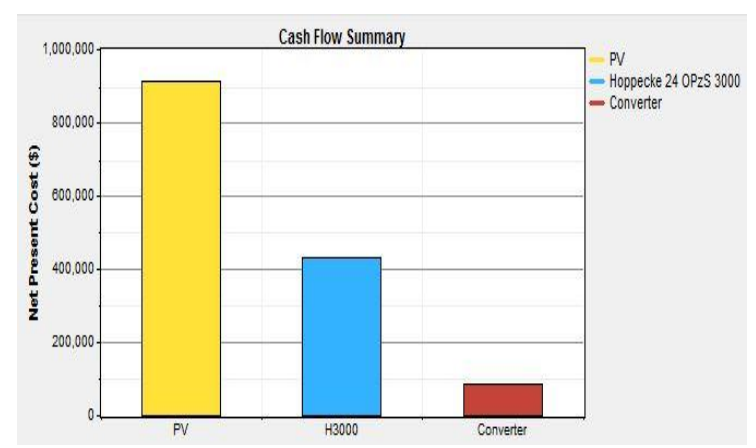

Fig. 8. Cash flow summary of different component of the hybrid power system

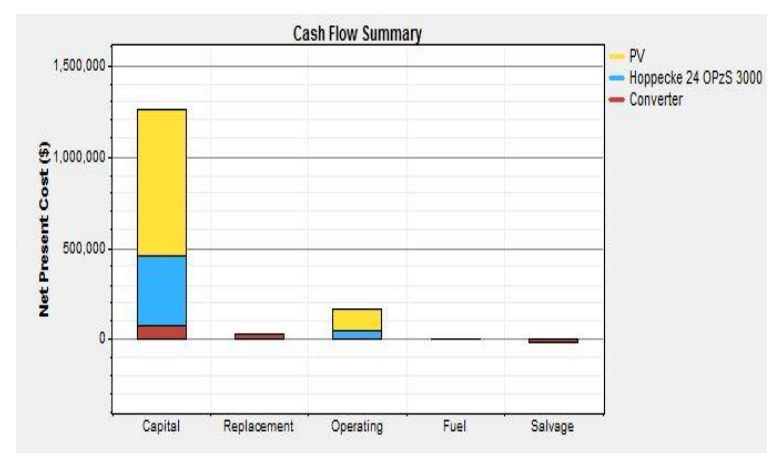

Fig. 9. Net Present Cost of different component by cost type

\subsection{SENSITIVITY ANALYSIS}

The results of the analysis of different system configurations depend upon several parameters which directly affect the system. These parameters include the wind speed, solar radiation, slope of the PV array etc. Variation of these parameters results in different values. Also these parameters don't remain the same over the time period. The 
software takes into account the changes in the values of different parameters that affect the system, as sensitivity variables, and simulates all the system configurations for each of the sensitivity variables. In this study wind speeds of $4.5,4.74,5,5.5,6,6.5,7$, and $7.5 \mathrm{~m} / \mathrm{s}$ ), solar radiation values of 5.5 , $5.95,6,6.5,6.5$ and $7 \mathrm{kWh} / \mathrm{m}^{2} /$ day) and slope of the PV array of $5^{\circ}, 10^{\circ}, 20^{\circ}, 24.4^{\circ}$, $25^{\circ}, 30^{\circ}, 35^{\circ}$, and $40^{\circ}$ has been taken as sensitivity variable. A total of 448 sensitivity cases were examined in this study. Figure 10 shows the optimization results in terms of wind speed and solar radiation for fixed PV array slope of $24.4^{\circ}$ and Figure 11 shows the optimization results in terms of wind speed and PV array slope for fixed solar radiation of $5.95 \mathrm{k} \mathrm{Wh} / \mathrm{m}^{2} /$ day. Figure 12 shows the relationship among PV array capacities, solar radiation values and levelized costs of energy. The selected site for this study at the red circled point at Figure 10 which shows that for the site's wind speed $4.74 \mathrm{~m} / \mathrm{s}$, wind energy will be incorporated in the optimized system only if the solar radiation of the site is 5.5 $\mathrm{kWh} / \mathrm{m}^{2} /$ day or less. Also it is evident from the Fig. 10 that the optimal system will be a solar-wind-battery hybrid system for the PV slope of $24.4^{\circ}$ if the wind speed is more than about $5.75 \mathrm{~m} / \mathrm{s}$.

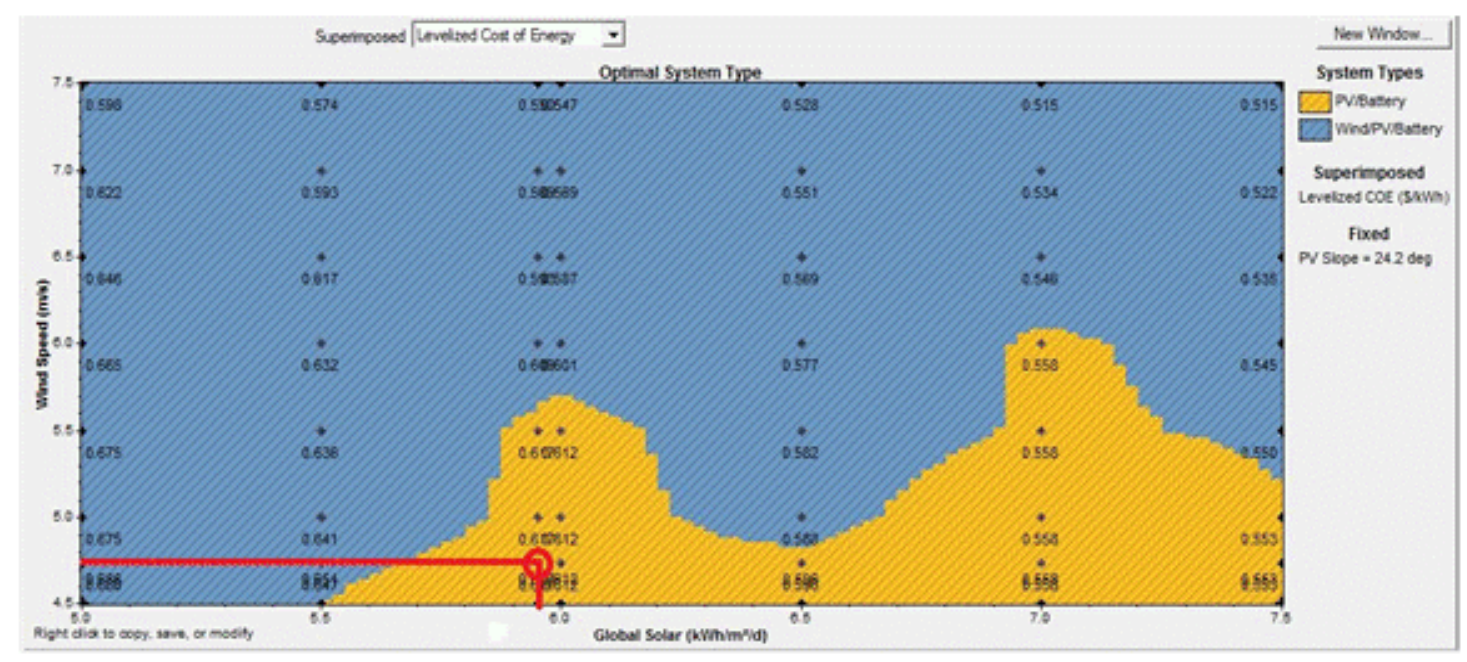

Fig. 10 The optimal system in terms of wind speed and solar radiation for fixed PV array slope

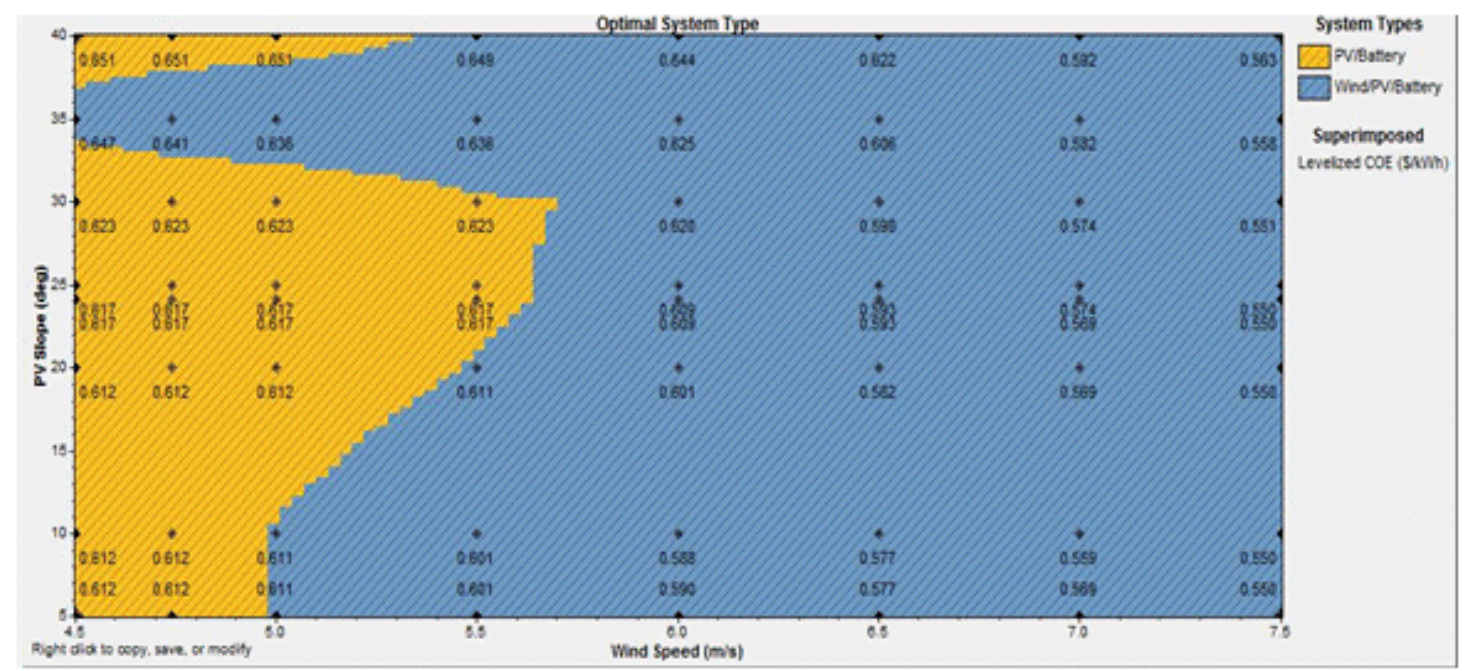

Fig. 11 The optimal system in terms of wind speed and PV slope 


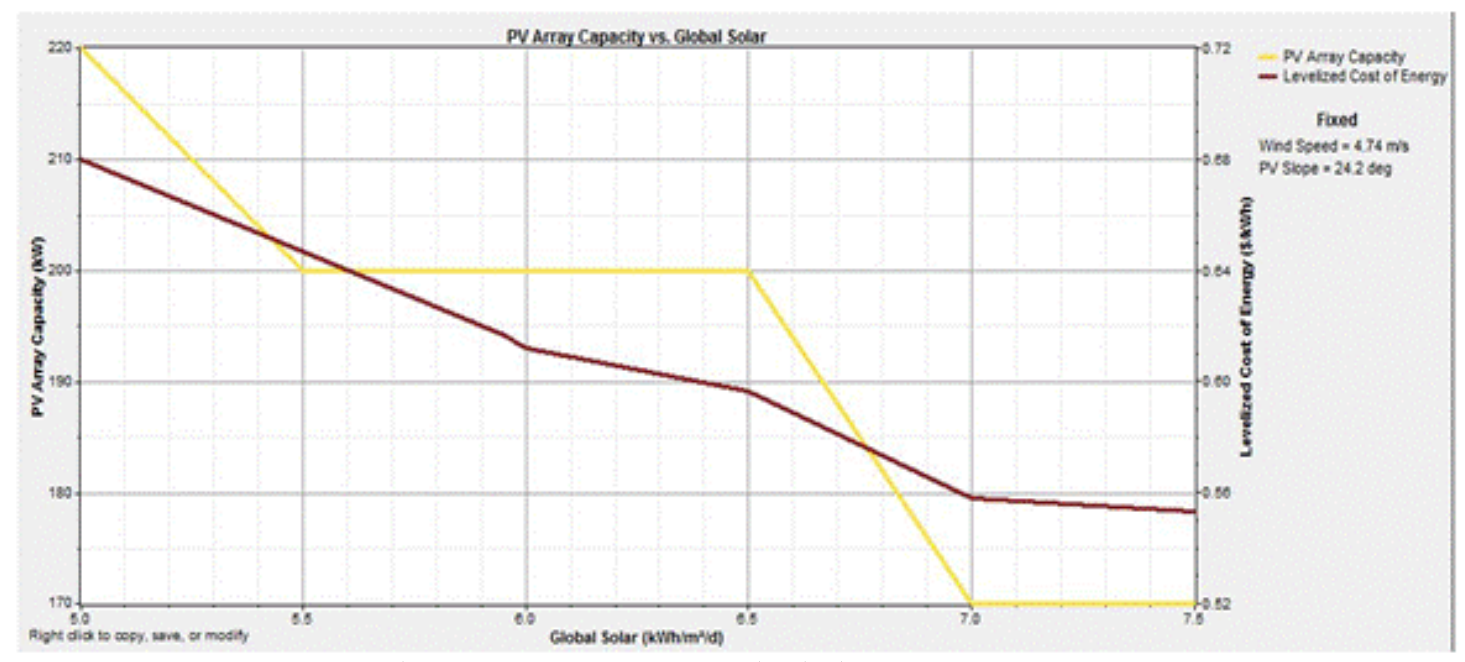

Fig. 12 Levelized cost of energy in terms of Global solar radiation and PV array capacity

\section{CONCLUSION}

This study was performed with a view to find an optimal wind-PV-battery hybrid power system to supply electricity to a community of Yanbu, a port city of KSA using HOMER. However, due to high solar energy intensity and poor wind resources at the site, the simulation results showed high intensity of solar radiation and poor wind energy potential, the optimal system proposed by the simulation tool is a that a PV-battery power system is the best solution with cost of energy of $0.617 \$ / \mathrm{kWh}$ at an average solar radiation of $5.95 \mathrm{kWh} / \mathrm{m}^{2} /$ day and a wind speed of $4.74 \mathrm{~m} / \mathrm{s}$. From the sensitivity analysis, it is evident that if the wind speed is more than almost $5.75 \mathrm{~m} / \mathrm{s}$ or if the solar radiation is $5.5 \mathrm{kWh} / \mathrm{m}^{2} /$ day or less in that location then the optimal system would be a wind-PV-battery hybrid system with the even lower cost of energy. Consideration of a diesel generator would further reduce the cost of energy and the excess amount of electricity generated. But considering the global warming and to limit the greenhouse emission from the system to zero no diesel generator has been used. However, an actual and detailed load profile of the location throughout the year would be very helpful to improve the analysis.

\section{REFERENCES}

[1] Matsuo, Y., Yanagisawa, A., \& Yamashita, Y. (2013), "A global energy outlook to 2035 with strategic considerations for Asia and Middle East energy supply and demand interdependencies”, Energy Strategy Reviews, 2(1), 79-91.

[2] Petroleum, B. (2015), "BP Statistical Review of World Energy June 2015 bp”, com/statistical review. Accessed: April, 2017.

[3] Dudley, B. (2012), "BP statistical review of world energy". June 2012. London, UK.

[4] Olivier, J. G. J., Janssens-Maenhout, G., Muntean, M., \& Peters, J. A. H. W. (2015), "Trends in global CO2 emissions: 2015 Report. PBL Netherlands Environmental Assessment Agency”, The Hague; European Commission, Joint Research Centre (JRC). Institute for Environment and Sustainability (IES).

[5] Outlook, BP Energy 2030. (2013). "London [dokument elektroniczny: http://www. bp.com/liveassets/bp_internet/globalbp/globalb p_uk_english/reports_and_publications/statistic al_energy_review_2011/STAGING/local_assets /pdf/BP_World_Energy_Outlook_booklet_201 3.pdf.

[6] Shaahid, S. M., \& El-Amin, I, (2009), "Techno-economic evaluation of off-grid hybrid photovoltaic-diesel-battery power systems for rural electrification in Saudi Arabia-a way 
forward for sustainable development". Renewable and Sustainable Energy Reviews, 13(3), 625-633.

[7] Rahman, M. M., Khan, M. M. U. H., Ullah, M. A., Zhang, X., \& Kumar, A. (2016), “A hybrid renewable energy system for a North American off-grid community”. Energy, 97, 151-160.

[8] Yang, H., Wei, Z., \& Chengzhi, L. (2009), "Optimal design and techno-economic analysis of a hybrid solar-wind power generation system”, Applied Energy, 86(2), 163-169

[9] Hansen, U. (1998), "Technological options for power generation”, The Energy Journal, 63-87.

[10] Nayar, C. V., Phillips, S. J., James, W. L., Pryor, T. L., \& Remmer, D. (1993), "Novel wind/diesel/battery hybrid energy system”, Solar energy, 51(1),65-78.

[11] Chowdhury, B. H., \& Rahman, S. (1988), "Analysis of interrelationships between photovoltaic power and battery storage for electric utility load management". IEEE Transactions on Power Systems, 3(3), 900-907.

[12] De Almeida, A. T., Martins, A., Jesus, H., \& Climaco, J. (1983), "Source reliability in a combined wind-solar-hydro system". IEEE Transactions on Power Apparatus and Systems, (6), 1515-1520.

[13] Abdi, D., \& Bitsuamlak, G. T. (2014). "Numerical evaluation of the effect of multiple roughnesschanges". Wind and Structures, 19(6), 585-601.

[14] Chen, T. H., \& Tran, V. T. (2015). "Prospects of wind energy on Penghu Island", Taiwan. Wind and Structures, 20(1), 1-13.

[15] Cook, N. J. (2014). "Detecting artefacts in analyses of extreme wind speeds". Wind and Structures, 19(3), 271-294.

[16] Han, T. H., Park, Y. H., Won, D., \& Lee, J. H. (2015). "Design feasibility of double-skinned composite tubular wind turbine tower". Wind and Structures, 21(6), 727-753.

[17] Ke, S., Yu, W., Wang, T., Zhao, L., \& Ge, Y. (2016). "Wind loads and load-effects of large scale wind turbine tower with different halt positions of blade". Wind and structures, 23(6), 559-575.
[18] Leitch, C. J., Ginger, J. D., \& Holmes, J. D. (2016). "Wind loads on solar panels mounted parallel to pitched roofs, and acting on the underlying roof". Wind and Structures, 22(3), 307-328.

[19] Luhur, M. R., Manganhar, A. L., Solangi, K. H., Jakhrani, A. Q., Mukwana, K. C., \& Samo, S. R. (2016). "A review of the state-of-the-art in aerodynamic performance of horizontal axis wind turbine". Wind and Structures, 22(1), 116.

[20] Sedghi, M., Hannani, S. K., \& Boroushaki, M. (2015). "Estimation of weibull parameters for wind energy application in Iran's cities". Wind and Structures, 21(2), 203-221.

[21] Kusakana, K., \& Vermaak, H. J. (2013), "Hybrid renewable power systems for mobile telephony base stations in developing countries". Renewable Energy, 51, 419-425.

[22] Nandi, S. K., \& Ghosh, H. R. (2010), "Prospect of wind-PV-battery hybrid power system as an alternative to grid extension in Bangladesh”. Energy, 35(7), 3040-3047.

[23] Lambert, T., Gilman, P., \& Lilienthal, P. (2006), "Micropower system modeling with HOMER. Integration of alternative sources of energy", 1(15), 379-418.

[24] Mondal, A. H., \& Denich, M. (2010), "Hybrid systems for decentralized power generation in Bangladesh". Energy for Sustainable Development, 14(1), 48-55.

[25] Bekele, G., \& Palm, B. (2010), "Feasibility study for a standalone solar-wind-based hybrid energy system for application in Ethiopia”. Applied Energy, 87(2), 487-495.

[26] Mudasser, M., Yiridoe, E. K., \& Corscadden, K. (2015), "Cost-benefit analysis of grid-connected wind-biogas hybrid energy production, by turbine capacity $\&$ site”. Renewable Energy, 80, 573-582.

[27] Rehman, S., \& Al-Hadhrami, L. M. (2010), "Study of a solar PV-diesel-battery hybrid power system for a remotely located population near Rafha”, Saudi Arabia. Energy, 35(12), 4986-4995. 


\section{الجدوى التقنية والاقتصادية لنظام قدرة هجين من الطاقة الشمسية الكهروضوئية مع طاقة الرياح

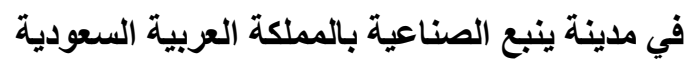 \\ حازم عبد العزيز موريا1، محمد عبداله الباكي²، محمد مصطفز الرحمن2، صدر الإسلام² 1 قسم تكنولوجيا الهنسة الميكانيكية، كلية ينبع الصناعية، ينبع الصناعية 41912، الملكة العربية السعودية 2 قسم الهندسة اليكانيكية والكيميائية، الجامعة الإسلامية للتكنولوجيا، بوردبازار ، غازيبور 1704، بنغلاديش}

الملخص:

تستخدم الطاقة الناتجة من المصادر المتجددة على نحو متزايد لتلبية طلبات الطاقة والحد من الآثار الضارة لحرق الوقود الأحفوري على البيئة. حيث تم دمج الطاقة الثمسية الضوئية ونوربينات الرياح مع مولد الديزل التقليدي للحد من استهلاك الوقود. المملكة العربية السعودية، كونها دولة ذات كثافة عالية من الإشعاع الثمسي، لديها إمكانيات جيدة لاستخدام نظام الطاقة الثمسية الكهروضوئية. في هذه الدراسة، تم تصميم موديل لنظام هجين للطاقة الثمسية والرياح باستخدام برنامج "هومر" للعثور على نظام مثالي لتلبية متطلبات الحمل لمجتمع مدينة ينبع. الحمل الرئيسي لمجتمع مكون من 500 شخص هو 556 كيلوو اط ساعة / يوم مع 68 كيلوواط خلال الذروة. وأظهر التحليل أن النظام الكهروضوئي 200 كيلوواط هو الأكثر جدوى من الناحية الاقتصادية لتلبية الطلب المقترح والحد الأدنى لتكلفة الطاقة لهذا النظام هو 0.617 دولار / كيلوواط ساعة. تم إجراء تحليل الحساسية بمتوسط سر عة الرياح و الإشعاع الشمسي المتفاوتة وتم تقديمها في هذه الدر اسة. 